\title{
Studi Kematian Ibu dan Kematian Bayi di Provinsi Sumatera Barat: Faktor Determinan dan Masalahnya
}

\section{Study of Maternal Mortality and Infant Mortality in West Sumatera Province: Problem and Determinant Factor}

\author{
U. Mariati* Z. Agus** D. Sulin** Masrul** Z. Amri* F. Arasy* Muslim* H. Hanum* Mohanis* F. Arma*
}

*Jurusan Kebidanan Politeknik Kesehatan Kementerian Kesehatan Padang, **Fakultas Kedokteran Universitas Andalas

\begin{abstract}
Abstrak
Salah satu tujuan yang hendak dicapai oleh World Health Organization pada tahun 2000 adalah health for all by year 2000. Beberapa indikator digunakan untuk mengukur pencapaian tersebut, diantaranya angka kematian bayi (AKB) dan angka kematian ibu (AKI). Dinas Kesehatan Sumatera Barat telah berhasil menurunkan AKB dan AKI selama 5 tahun terakhir, akan tetapi angka-angka tersebut tidak menggambarkan angka yang sebenarnya karena hanya diperoleh berdasarkan prediksi perhitungan statistik kependudukan. Angka tersebut juga tidak dapat memperlihatkan disparitas antarwilayah dan kelompok sosial ekonomi di Sumatera Barat. Penelitian ini dilakukan untuk mendapatkan AKB dan AKI yang tepat serta mengetahui faktor determinan dan permasalahannya di Sumatera Barat pada tahun 2007. Desain penelitian adalah Direct Household Survey Method dengan pendekatan prospektif. Penelitian dilakukan di 19 kabupaten/kota di Provinsi Sumatera Barat dari tanggal 1 Januari sampai 31 Desember 2007. Hasil penelitian menunjukkan AKB dan AKI Sumatera Barat tahun 2007 berkisar 28,4 per 1.000 kelahiran hidup dan 211,9 per 100.000 kelahiran hidup. Asfiksia dan perdarahan postpartum merupakan penyebab kematian utama ibu dan bayi. Dinas Kesehatan Sumatera Barat dan pemerintahannya harus mempunyai komitmen yang kuat untuk membangun jaringan kerja yang efektif untuk menurunkan AKB dan AKI di Sumatera Barat.

Kata kunci: Angka kematian bayi, angka kematian ibu, asfiksia, postpartum
\end{abstract}

\footnotetext{
Abstract

One of the main goals that WHO wants to reach in 2000 is Health for All Year 2000. Some of indicators have been using to measure the goals, such as infant mortality rate (IMR) and maternal mortality rate (MMR). West Sumatera Health Office had been successed reducing IMR and MMR for over 5 years, but the score was not mentioned the exact number because this measurement just using national statistic measurement. It also could not describe the disparity between the area and sosial group in West Sumatera. This research aim is to get the exact number of IMR and MMR,
}

determinat factors and its problems in West Sumatera in 2007. The study desain was Direct Household Survey Method with prospective approach. The research was done in 19 different government district in West Sumatera from January $1^{\text {st }}$ until December $31^{\text {st }} 2007$. Result of this research found IMR and MMR of West Sumatera in 2007 is 28,4 per 1.000 birth life and 211,9 per 100.000 birth life. Asphyxia and postpartum bleeding is the main cause of infant and maternal death. West Sumatera Health Office and its government should have a strong commitment to build effective networking to reduce IMR and MMR in West Sumatera.

Key words: Infant mortality rate, maternal mortality rate, asphyxia, postpartum

\section{Pendahuluan}

Salah satu tujuan yang hendak dicapai oleh World Health Organization (WHO) yang telah dirumuskan dalam pertemuan Alma Alta tahun 1978 adalah mencapai sehat semua di tahun 2000, yang lebih dikenal dengan health for all by year 2000. Untuk mencapai tujuan itu, berbagai program dengan berbasis Primary Health Care telah dilaksanakan untuk meningkatkan derajat kesehatan. Beberapa indikator yang digunakan oleh WHO untuk mengukur tingkat keberhasilan program-program tersebut, antara lain angka kematian bayi (AKB), angka kematian balita (AKABA), angka harapan hidup (life expectancy), dan angka kematian maternal (Maternal Mortality Rate, MMR) atau angka kematian ibu (AKI). 1,2

WHO memperkirakan terdapat sekitar 585.000 kematian ibu setiap tahun yang disebabkan komplikasi ke-

Alamat Korespondensi: Ulvi Mariati, Jurusan Kebidanan Politeknik Kesehatan Kementerian Kesehatan Padang, Komplek Kesehatan Gunung Pangilun Jl. Gajah Mada Padang, Hp.08126602331,e-mail: mama_ulvi@yahoo.com 
hamilan, persalinan, dan nifas dimana sebagian besarnya dapat dicegah. AKI di dunia menurun dari 620 per 100.000 kelahiran hidup tahun 1955 menjadi 230 per 100.000 kelahiran hidup pada tahun 1995 dan diharapkan semakin menurun hingga hanya mencapai 140 per 100.000 kelahiran hidup pada tahun 2025. Sebagian besar $(95 \%)$ dari kematian ibu tersebut terjadi di negaranegara berkembang. 3,4

AKI di Indonesia saat ini masih tinggi dan belum seperti yang diharapkan. Survei Demografi dan Kesehatan Indonesia (SDKI) 2002-2003 menunjukkan bahwa AKI di Indonesia pada tahun 2003 sudah turun mencapai 307 per 100.000 kelahiran hidup dari angka 390 per 100.000 kelahiran hidup berdasarkan laporan tahun 1994. Namun, apabila dibandingkan dengan negara tetangga terdekat dan bila dibandingkan dengan target AKI dalam Program Pembangunan Nasional (Propenas) 2000 yang lalu sebesar 225 per 100.000 kelahiran hidup maka pencapaian angka ini tentu saja masih sangat jauh. ${ }^{3}$

Pemerintah Indonesia bersama 188 negara lainnya pada bulan September tahun 2000 sepakat menandatangani Deklarasi Milenium Persatuan Bangsa-Bangsa yang menghasilkan sekumpulan tujuan yang disebut Millenium Development Goals (MDGs) dan sejumlah kebijakan khususnya yang harus terukur dan bisa dicapai pada tahun 2015. Pemerintah Indonesia yang turut menandatangani kesepakatan ini berkomitmen penuh untuk melaksanakan dan memonitor perkembangannya. Setiap sasaran dalam MDGs memiliki target-target khusus. Sebagai acuan, digunakan beberapa indikator diantaranya adalah pengurangan angka kematian anak sampai dua per tiga angka kematian anak dibawah 5 tahun pada tahun 2015 dan peningkatan angka kesehatan ibu dengan target mengurangi sampai tiga per empat rasio perempuan yang meninggal karena melahirkan pada tahun 2015.1,3

Data profil kesehatan Provinsi Sumatera Barat memperlihatkan adanya keberhasilan dalam peningkatan derajat kesehatan masyarakat yang dilihat dari beberapa indikator. AKB Sumatera Barat dapat diturunkan dari 74 per 1000 kelahiran hidup (1990) menjadi 43,9 per 1000 kelahiran hidup (2003), sedangkan AKABA menurun dari 72 per 1000 kelahiran hidup (2002) menjadi 63 per 1000 kelahiran hidup (2003). AKI Sumatera Barat juga menunjukkan penurunan dari 540 per 100.000 kelahiran hidup (1986) menjadi 310 per 100.000 kelahiran hidup (2002) dan 305 per 100.000 kelahiran hidup (2003).5,6

Angka-angka yang ditampilkan tersebut bukan yang sebenarnya melainkan angka-angka yang diperoleh berdasarkan prediksi yang dikembangkan berdasarkan perhitungan statistik kependudukan. Oleh karena negara kita sampai saat ini belum memiliki catatan kependudukan yang baik maka ketepatan nilai angka ini ke- mungkinan besar masih jauh dari kenyataan yang sebenarnya. Disamping itu, angka-angka tersebut tentu saja tidak dapat memperlihatkan disparitas antarwilayah kabupaten/kota, padahal disparitas AKI dan AKB antarwilayah kabupaten/kota ataupun disparitas antarkelompok sosial ekonomi masyarakat sangat diperlukan untuk mempertajam sasaran pembangunan, khususnya kawasan pinggiran dan kabupaten hasil pemekaran pascareformasi.

Menteri Kesehatan dengan Surat Keputusan Menteri No.1202/Menkes/SK/VII/2003 pada tahun 2003 menetapkan sasaran pembangunan kesehatan yang disebut sebagai Indonesia Sehat 2010 dengan sasaran yang paralel dengan sasaran MDGs. Surat Keputusan Menteri Kesehatan tersebut telah menetapkan target AKI sebesar 150 per 100.000 kelahiran hidup, AKB 40 per 100.000 kelahiran hidup, dan angka harapan hidup 67,9 tahun, padahal disparitas antarwilayah masih sangat lebar.

Berdasarkan latar belakang tersebut maka perlu diketahui AKI, AKB, dan AKABA di Sumatera Barat yang sebenarnya dengan tepat berdasarkan hasil penelitian. Disamping itu, faktor-faktor penyebab kematian sebagian besar ibu, bayi, dan balita di Sumatera Barat juga belum diketahui. Untuk itu, dilakukan penelitian AKI, AKB, dan AKABA di Provinsi Sumatera Barat serta faktorfaktor yang mempengaruhinya tahun 2007.

\section{Metode}

Penelitian dilaksanakan di 19 kabupaten/kota di Provinsi Sumatera Barat yang terdiri dari 154 kecamatan, 230 kelurahan, dan 3.152 desa/jorong/kampung. Pelaksanaan penelitian terdiri dari 2 tahap yaitu tahap persiapan yang dilakukan pada bulan September sampai Desember 2006 dan tahap pelaksanaan yang dilakukan dari tanggal 1 Januari sampai 31 Desember 2007. Desain penelitian adalah Direct Household Survey Method dengan pendekatan prospektif. Populasi yang diambil adalah semua ibu hamil, ibu melahirkan, ibu nifas, bayi, dan balita yang ada di Sumatera Barat selama 1 tahun. Pengambilan sampel dilakukan secara total sampling dengan syarat memenuhi kriteria inklusif dan kriteria eksklusif. Kriteria inklusif sampel adalah semua ibu hamil, ibu yang melahirkan, ibu nifas, bayi, dan balita yang tinggal dan berdomisili selama 6 bulan atau lebih di suatu desa/daerah di Provinsi Sumatera Barat, sedangkan kriteria eksklusif adalah sebaliknya.

Data penelitian diperoleh melalui pengisian form bulanan, catatan kematian, dan catatan kelahiran yang telah disediakan serta proses wawancara yang dilakukan oleh peneliti provinsi dan kabupaten/kota yang dibantu oleh tenaga enumerator yang telah mendapatkan pelatihan sebelumnya (bidan desa, petugas kesehatan puskesmas yang ditunjuk, dan penanggung jawab desa yang bertugas di setiap desa yang berjumlah 2.551 orang). Data yang di- 
dapatkan berisi karakteristik ibu, penyebab kematian ibu hamil, ibu melahirkan dan ibu nifas, status kesehatan bayi dan balita serta akses ke pelayanan kesehatan (meliputi ada tidaknya antenatal care (ANC), deteksi dini kehamilan berisiko, kunjungan baru ibu hamil (K1) dan K4, pertolongan persalinan, postnatal care, dan status imunisasi dasar bayi/balita).

Pengumpulan data dan form bulanan dilakukan dengan mekanisme yang teratur dan terorganisasi. Form bulanan yang telah dibuat oleh bidan desa diserahkan setiap tanggal 1 ke penanggung jawab puskesmas yang selanjutnya melakukan verifikasi data bersama penanggung jawab kabupaten/kota untuk memastikan kebenaran data. Form yang benar kemudian dikumpulkan penanggung jawab kabupaten/kota kepada peneliti provinsi. Apabila terdapat kematian ibu, bayi atau balita maka bidan desa harus segera melaporkan kematian tersebut kepada penanggung jawab puskesmas yang kemudian melaporkannya kepada peneliti provinsi. Penelusuran data kematian/validasi data akan dilakukan oleh peneliti provinsi atau penanggung jawab kabupaten/kota dalam waktu kurang dari 7 hari dari tanggal kematian. Semua data yang terkumpul diolah secara komputerisasi dan dianalisa untuk menentukan insiden kematian ibu, bayi, dan balita serta distribusi penyebab kematian. Analisa data penelitian ini meliputi analisa univariat yang dilakukan terhadap tiap-tiap variabel penelitian dan analisa bivariat dengan menggunakan uji chi square.

\section{Hasil}

\section{Keadaan Umum}

Provinsi Sumatera Barat mempunyai luas wilayah $42.229 .730 \mathrm{~km}^{2}$ dan dikelilingi oleh 4 provinsi tetangga yaitu Riau, Jambi, Bengkulu, dan Sumatera Utara. Provinsi ini terbagi atas 19 kota kabupaten/kota dimana 5 kabupaten/kota merupakan kabupaten/kota pemekaran dari 14 kabupaten/kota sebelumnya. Secara geografis, sebagian besar pemukiman penduduk berada di pegunungan sepanjang Bukit Barisan dengan ketinggian antara 100-900 meter dari permukaan laut dan mempunyai topografi mulai dari datar, bergelombang sampai bergunung.

\section{Fasilitas Pelayanan dan Sumber Daya Kesehatan}

Provinsi Sumatera Barat memiliki fasilitas pelayanan kesehatan yang relatif cukup memadai. Jumlah pusat pelayanan kesehatan di Sumatera Barat mencapai 7.557 yang terdiri dari 20 rumah sakit pemerintah, 28 rumah sakit swasta, 3 rumah sakit TNI/Polri, 226 puskesmas, 828 puskesmas pembantu, dan 6.452 posyandu. Namun, hal ini tidak diikuti dengan ketersediaan sumber daya kesehatan yang memadai terutama tenaga kesehatan di lapangan. Data Dinas Kesehatan Sumatera Barat tahun 2007 menunjukkan jumlah tenaga kesehatan lapangan
Tabel 1. Jumlah Dokter, Bidan, dan Perawat di Tingkat Lapangan di Provinsi Sumatera Barat Tahun 20077

\begin{tabular}{llcc}
\hline & & \multicolumn{2}{l}{ Jumlah per $\mathbf{1 0 0 . 0 0 0}$ penduduk } \\
\cline { 3 - 4 } Jumlah Tenaga & Jumlah & $\mathbf{2 0 0 7}$ & Target 2007 \\
\hline Bidan & 1.515 & 34 & 70 \\
Perawat & 1.510 & 33 & 42 \\
Dokter puskesmas & 443 & 10 & 27 \\
\hline Total & $\mathbf{3 . 4 6 8}$ & & \\
\hline
\end{tabular}

belum memadai bila dibandingkan sebaran-sebaran desadesa tempat pemukiman penduduk (Lihat Tabel 1).

Wilayah yang demikian luas dan beratnya medan, terutama di daerah-daerah pemekaran merupakan faktor yang menyebabkan distribusi petugas kesehatan di lapangan belum tersebar dengan baik.

\section{Status Kesehatan Penduduk}

Data Dinas Kesehatan Sumatera Barat memperlihatkan adanya peningkatan derajat kesehatan masyarakat Sumatera Barat yang dapat dilihat dari beberapa indikator, antara lain AKI, AKB, dan umur harapan hidup (UHH). AKI Sumatera Barat turun dari 390 per 100.000 kelahiran hidup pada tahun 2000 menjadi 240 per 100.000 kelahiran hidup pada tahun 2005. AKB Sumatera Barat juga mengalami penurunan secara signifikan selama 5 tahun terakhir yaitu dari 49,67 per 1.000 kelahiran hidup tahun 2000 menjadi 38 per 1000 kelahiran hidup tahun 2005. Peningkatan ketersediaan fasilitas atau aksesibilitas ke pelayanan kesehatan serta petugas kesehatan merupakan faktor penting penurunan AKB tersebut. Penurunan AKB yang cukup bermakna juga akan berpengaruh terhadap peningkatan UHH. Data Dinas Kesehatan menunjukkan UHH Sumatera Barat meningkat dari 64,4 tahun (2000) menjadi 68,4 tahun (2005), walaupun angka ini masih dibawah kenaikan UHH provinsi tetangga.

\section{Karakteristik Ibu Melahirkan}

Sepanjang tahun 2007 terdapat 75.018 orang ibu yang melahirkan anak hidup. Distribusi ibu melahirkan berdasarkan karakteristik ibu menunjukkan bahwa $81,9 \%$ ibu melahirkan berusia antara 20-35 tahun, $60 \%$ berpendidikan setingkat SLTP-SLTA, $82 \%$ tidak bekerja, $79,8 \%$ mempunyai anak $<3$ orang, 89,2\% melahirkan secara normal, dan $88,3 \%$ memilih petugas kesehatan sebagai penolong proses persalinannya.

\section{Kematian Ibu}

Sekitar 90.000 kehamilan sepanjang tahun 2007 terdapat 159 kematian ibu, baik dari proses kehamilan, per- 
Tabel 2. Distribusi Angka Kematian Ibu Menurut Umur, Paritas, dan Tingkat Pendidikan Ibu

\begin{tabular}{llccc}
\hline Karakteristik Responden & Kategori & Jumlah Bayi Lahir & Kematian Ibu & Angka Kematian Ibu \\
\hline Umur & $<20$ dan $>35$ & 13.578 & 64 & 471,4 \\
& $20-35$ & 61.440 & 95 & 154,6 \\
Paritas & $>3$ & 56.864 & 64 & 471,4 \\
& $\leq 3$ & 18.154 & 95 & 154,6 \\
Pendidikan & SMP/kurang & 44.111 & 21 & 301,5 \\
& SMA sederajat & 25.056 & 53 & 85,8 \\
\hline
\end{tabular}

salinan maupun nifas sehingga AKI di Sumatera Barat tahun 2007 adalah 211,9 per 100.000 kelahiran hidup. Distribusi AKI menurut kabupaten/kota menunjukkan bahwa dari 19 kabupaten/kota yang ada di Sumatera Barat hanya 3 kabupaten/kota yang telah mencapai sasaran MDGs dan Indonesia Sehat 2010 yaitu kabupaten Tanah Datar, Kota Solok, dan Kota Sawahlunto (AKI $<120$ per 100.000 kelahiran hidup). Tiga belas kabupaten/kota lainnya masih sangat jauh dari target MDGs dan Indonesia Sehat 2010. AKI Sumatera Barat lebih tinggi terjadi pada kelompok ibu yang melahirkan pada usia < 20 tahun atau $>35$ tahun, mempunyai paritas lebih dari 3 , dan berpendidikan rendah (SMP/kurang) (Lihat Tabel 2).

Hasil penelitian juga memperlihatkan AKI lebih tinggi terjadi pada ibu yang cara persalinannya ditolong dengan tindakan $(\mathrm{AKI}=862,6$ per 100.000 kelahiran hidup) dibandingkan ibu yang persalinannya berlangsung spontan $(\mathrm{AKI}=164,5$ per 100.000 kelahiran hidup). Tingginya AKI pada kelompok ini disebabkan karena tindakan terhadap ibu umumnya dilakukan setelah melalui perjalanan yang panjang dan sangat melelahkan dari petugas kesehatan atau dukun dengan fasilitas yang kurang memadai. Keputusan merujuk juga tidak diambil dengan segera karena harus melalui proses yang panjang di lingkungan keluarga ibu.

\section{Karakteristik Bayi}

Sepanjang tahun 2007 , terdapat 75.018 bayi lahir hidup dimana $53,6 \%$ diantaranya berjenis kelamin lakilaki dan $47,4 \%$ berjenis kelamin perempuan. Bila dilihat dari urutan anak dalam keluarga, 31\% bayi merupakan anak pertama; 29,2\% anak kedua; 19,7\% anak ketiga; dan sisanya anak kelima sampai kedelapan. Rata-rata panjang dan berat bayi yang lahir pada tahun 2007 di Sumatera Barat adalah 48,46 cm (rentang 45-55 cm) dan 3155 gram (rentang 1.400-3.200 gram). Distribusi bayi berdasarkan tingkat pendidikan dan pekerjaan orang tua menunjukkan sebagian besar bayi mempunyai bapak yang bekerja sebagai petani $(41,1 \%)$, ibu yang tidak be- kerja $(82 \%)$ serta berpendidikan SLTP-SLTA $(63,5 \%$ dan $59,5 \%$ ).

Distribusi bayi berdasarkan cara dan penolong persalinan memperlihatkan sebagian besar bayi lahir secara normal $(89,2 \%)$ dan ditolong oleh bidan dalam proses kelahirannya $(69,4 \%)$. Pemilihan penolong persalinan merupakan faktor yang penting bagi pengurangan risiko kematian pada bayi dan ibu.

Penelitian ini menemukan adanya 2.136 kasus kematian bayi dan 75.018 kelahiran hidup di Sumatera Barat sepanjang tahun 2007 sehingga AKB Sumatera Barat tahun 2007 berkisar 28,4 per 1000 kelahiran hidup. AKB tertinggi terjadi di Kota Solok (47,9 per 1000 kelahiran hidup), sedangkan AKB terendah terjadi di Kota Bukittinggi (14,9 per 1000 kelahiran hidup). Distribusi AKB berdasarkan karakteristik ibu menunjukkan AKB lebih tinggi terjadi pada kelompok ibu yang berumur < 20 tahun atau $>35$ tahun, berparitas lebih dari 3, berpendidikan rendah (SMP/kurang), dan ditolong oleh tenaga nonkesehatan dalam proses persalinannya (Lihat Tabel 3).

Penyebab kematian bayi di Sumatera Barat sepanjang tahun 2007 adalah asfiksia $(65,3 \%)$, kelainan kongenital $(11,8 \%)$, infeksi $(8,3 \%)$, diare $(6,1 \%)$, tetanus neonatorum $(1,4 \%)$, dan lain-lain $(7,1 \%)$. Berdasarkan distribusi frekuensi umur kematian bayi diketahui bahwa 51,5\% kematian bayi terjadi pada saat bayi berumur lebih dari 28 hari, $41,3 \%$ saat masa perinatal $(<7$ hari), dan $7,2 \%$ saat masa neonatal (7-28 hari).

\section{Pembahasan}

Banyak faktor yang memberikan kontribusi terhadap kematian maternal diantaranya adalah penolong persalinan, tempat persalinan, ANC yang tidak sesuai dengan ketentuan atau tidak melaksanakan ANC serta faktor pihak ibu (paritas, status kesehatan, status gizi, dan kebersihan diri) merupakan faktor yang penting.

Hasil penelitian memperlihatkan bahwa penyebab utama kematian ibu di Sumatera Barat sepanjang tahun 2007 adalah perdarahan (32\%), eklampsia (14\%), par- 
Mariati, Agus, Sulin, Masrul, Amri, Arasy, Muslim, Hanum, Mohanis \& Arma, Studi Kematian Ibu dan Kematian Bayi

Tabel 3. Distribusi Angka Kematian Bayi Menurut Umur, Paritas, Pendidikan, dan Penolong Persalinan Ibu

\begin{tabular}{llccc}
\hline Karakteristik Responden & Kategori & Bayi Lahir Hidup & Bayi Meninggal Angka Kematian Bayi \\
\hline Umur & $<20$ dan $>35$ & 13.578 & 553 & 40,8 \\
& $20-35$ & 61.440 & 1.583 & 25,8 \\
Paritas & $>3$ & 16.979 & 897 & 52,8 \\
& $\leq 3$ & 59.039 & 1.239 & 21 \\
Pendidikan & SMP/kurang & 44.111 & 1.937 & 43,9 \\
& SMA/sederajat & 25.056 & 106 & 4,2 \\
Penolong persalinan & Perguruan tinggi & 5.851 & 93 & 15,9 \\
& Non nakes & 8.252 & 456 & 55,3 \\
& Nakes & 66.766 & 1680 & 25,2 \\
\hline
\end{tabular}

tus lama (12\%), infeksi (11\%), abortus (14\%), penyakit jantung $(5 \%)$, dan lain-lain (12\%). Proporsi kematian ibu karena perdarahan lebih banyak terjadi pada ibu dengan paritas $>3$ orang $(58,1 \%)$ dibandingkan ibu dengan paritas $\leq 3$ orang. Kasus kematian ibu akibat perdarahan terjadi pada persalinan yang ditolong oleh dukun $(30 \%)$. Perdarahan ibu terjadi karena retensi plasenta, anemia berat, partus lama, dan lainnya. Perdarahan postpartum dapat dikendalikan melalui kontraksi dan retraksi serat-serat miometrium. Kegagalan mekanisme akibat gangguan fungsi miometrium itu yang disebut dengan atonia uteri yang merupakan penyebab utama terjadinya perdarahan postpartum. ${ }^{8}$ Penyebab kematian ibu yang cukup tinggi pada persalinan disamping perdarahan adalah pre-eklampsia $(30 \%)$. Pre-eklampsia ditandai dengan edema, hipertensi, dan proteinuria. Sedangkan penyebab utama kematian eklampsia adalah edema paru yang disertai dengan gangguan fungsi ginjal dimana filtrasi glomerulus turun sampai $50 \%$ dari normal sehingga menyebabkan diuresis dan berlanjut ke oliguri bahkan sampai anuri (gagal ginjal). Pre-eklampsia didapatkan spasmus pembuluh darah disertai dengan retensi garam dan air, spasmus pembuluh darah yang hebat hanya dapat dilewati oleh 1 sel darah merah. Bila spasmus ini ditemukan di seluruh tubuh menyebabkan tekanan darah meningkat untuk mengatasi tahanan perifer agar oksigenisasi jaringan dapat dicukupi. Hal ini menyebabkan terjadinya perubahan pada otak dimana resistensi pembuluh darah dalam otak pada hipertensi dalam kehamilan lebih meningkat terjadi pada eklampsia. ${ }^{9-11}$

Penyebab kematian ibu yang lain adalah partus lama. Persalinan yang berlangsung lebih dari 24 jam digolongkan partus lama. Permasalahan harus dikenali dan diatasi sebelum batas waktu 24 jam tercapai. Sebagian besar partus lama menunjukkan perpanjangan kala 1, apapun yang menjadi penyebabnya, serviks gagal membuka penuh dalam jangka waktu 14 jam. Sebab utama dari partus lama adalah disproporsi feto pelvik, malpresentasi dan malposisi serta kerja uterus yang tidak efisien, termasuk serviks yang kaku. Disamping itu, primigraviditas dan ketuban pecah dini ketika serviks masih menutup, keras, dan belum mendatar. ${ }^{11,12}$

Besarnya jumlah kasus kematian ibu di rumah sakit, terutama Rumah Sakit Umum Pemerintah (RSUP) M. Djamil merupakan hal menarik yang ditemukan dalam penelitian. Hal ini disebabkan oleh beberapa faktor yaitu jauhnya jarak antara rumah sakit dengan tempat asal rujukan ibu, keterlambatan dukun atau petugas kesehatan merujuk, keterlambatan pengambilan keputusan oleh keluarga, kelalaian ibu dalam memeriksakan diri saat hamil, faktor petugas rumah sakit (terutama rumah sakit umum daerah) yang belum memiliki science of crisis yang memadai serta masih banyaknya dukun tidak terlatih yang memberikan jasa pemeriksaan kehamilan dan pertolongan persalinan.

Oleh karena itu, untuk mengurangi kematian ibu terdapat beberapa masalah yang perlu ditelusuri dan diperbaiki lebih lanjut yaitu manajemen pelayanan kesehatan ibu dan anak (KIA) yang belum bekerja secara efektif, sumber daya kesehatan yang belum memadai, dan perilaku masyarakat terhadap kesehatan yang masih rendah.

Proporsi penyebab kematian bayi dengan asfiksia, diare, dan infeksi lebih besar pada ibu dengan paritas $\leq 3$ orang $(65,6 \% ; 6,5 \%$; dan $9,3 \%)$ dan berpendidikan SMP kebawah $(68 \%$; 6,5\%; dan 10,1\%). Ibu yang mempunyai tingkat pendidikan rendah mempunyai kecenderungan untuk mengalami kematian bayi yang lebih besar. Hal ini terjadi karena keterbatasan pengetahuan ibu dalam merawat bayinya sehingga berisiko tinggi untuk terjadinya diare dan infeksi. Proporsi penyebab kematian bayi dengan kelainan konginetal dan penyebab lain lebih besar pada ibu dengan paritas $>3$ orang $(12,6 \%$ dan $7,7 \%)$ dan berpendidikan SMA keatas $(12,4 \%$ dan $7,8 \%$ ). Bayi yang dilahirkan dengan kelainan kongenital mayor memiliki risiko kematian 34,8 kali lebih tinggi 
dibandingkan dengan bayi yang dilahirkan tidak mengalami kelainan kongenital mayor.

Bila dihubungkan penyebab kematian bayi dengan tempat persalinan berlangsung akan ditemukan bahwa $76,9 \%$ kematian bayi karena asfiksia terjadi pada persalinan di dukun. Asfiksia neonatorum yaitu suatu keadaan bayi baru lahir yang gagal bernafas secara spontan dan teratur segera setelah lahir. Keadaan ini sering disertai dengan hipoksia, hiperkapnia, dan berakhir dengan asidosis. Hipoksia terjadi pada bayi asfiksia yang dapat menghambat adaptasi bayi baru lahir terhadap kehidupan ekstra uterin. ${ }^{13,14}$

Kematian bayi karena kelainan kongenital sebesar $16,9 \%$. Kelainan kongenital merupakan kelainan dalam pertumbuhan struktur tubuh bayi yang timbul sejak kehidupan konsepsi. Kelainan kongenital merupakan penyebab penting terjadinya abortus, lahir mati atau kematian segera setelah lahir. Banyak faktor yang menyebabkan terjadinya kelainan kongenital, diantaranya kelainan genetik, mekanik, infeksi, obat-obatan, umur ibu, hormonal, radiasi, dan gizi. Kelainan kongenital yang utama adalah kelainan jantung dimana kematian bayi terjadi $80 \%$ dalam tahun pertama dan sepertiganya meninggal pada minggu pertama kehidupannya. Penyebab kelainan jantung bawaan dapat bersifat eksogen yaitu infeksi rubella, obat-obat yang diminum ibu, dan radiasi. ${ }^{13}$

Kematian bayi karena infeksi mempunyai proporsi yang cukup besar dibandingkan dengan penyebab kematian yang lainnya. Infeksi interanatal lebih sering terjadi dimana mikroorganisme dari vagina naik dan masuk ke dalam rongga amnion setelah ketuban pecah. Interval waktu lebih kurang 12 jam antara pecahnya ketuban dan lahirnya bayi. Pecahnya ketuban mempunyai peranan penting terhadap timbulnya plasentitis dan amnionitis. Infeksi dapat pula terjadi walaupun ketuban masih utuh, misalnya pada partus lama dan sering sekali dilakukan manipulasi vagina. Infeksi lain terjadi pada janin pneumonia kongenital, septisemia blenoria, dan oral trush. Kasus ini sering terjadi pada persalinan di rumah ibu, sedangkan proporsi kematian bayi karena penyebab lainnya lebih besar terjadi di rumah sakit. ${ }^{13}$

Kematian bayi karena diare ditemukan sebesar $13,6 \%$. Kasus ini lebih tinggi pada neonatus dimana penyebab epidemi diare dengan mortalitas yang tinggi disebabkan oleh bakteri Escherichia coli. Bakteri Escherichia coli tidak dapat menembus mukosa usus tetapi dapat bersarang dalam lumen usus. Bakteri ini melepaskan toksin yang mengakibatkan terjadinya sekresi usus meningkat sehingga terjadi dehidrasi dan asidosis. Keadaan ini banyak ditemui pada persalinan di puskesmas. ${ }^{13}$

Selain itu, ditemukan juga penyebab kematian bayi $2,4 \%$ disebabkan oleh tetanus neonatorum yang dise- babkan oleh Clostridium tetani dimana toksinnya dapat menghancurkan sel-sel darah merah, merusak leukosit, dan merupakan tetanospasmin yaitu toksin neurotropik yang menyebabkan ketegangan dan spasma otot. Komplikasi terutama karena spasma otot pernapasan dan obstruksi saluran pernapasan yang dapat menyebabkan terjadinya asfiksia. Kematian akibat kejadian tetanus neonatorum ini ditemukan $80 \%$ pada neonatus. ${ }^{13-15}$

Penyakit tetanus neonatorum terjadi dimana spora Clostridium tetani masuk melalui luka tali pusat karena perawatan yang tidak steril, misalnya tali pusat yang dipotong dengan bambu, gunting yang tidak steril atau tali pusat diberi abu, tanah, daun-daunan, dan lain-lain. Perjalanan penyakit lebih cepat dan lebih berat dengan gejala sangat spesifik yaitu bayi tiba-tiba panas, tidak mau menyusu, sianosis, adanya gejala trismus (mulut mencucu), kejang, dan kaku kuduk. Kasus ini banyak terjadi pada persalinan di bidan praktek swasta (BPS). ${ }^{13-18}$

Hasil penelitian menunjukkan bahwa penyebab kematian balita di Sumatera Barat adalah demam (18,9\%), kejang $(13,5 \%)$, diare $(10,8 \%)$, dan gizi buruk $(5,4 \%)$ dimana $38,7 \%$ meninggal pada usia $12-23$ bulan dan $63,8 \%$ pada usia $24-59$ bulan. Proporsi kematian balita lebih tinggi pada balita yang mempunyai ibu dengan paritas $\leq 3$ orang $(63,8 \%)$ dibandingkan ibu dengan paritas $>3$ orang $(38,7 \%)$.

\section{Kesimpulan}

AKI dan AKB di Provinsi Sumatera Barat tahun 2007 tidak terlalu tinggi, akan tetapi disparitas antarkawasan dan kelompok sosial masih lebar. Hal ini terlihat dari masih tingginya AKI dan AKB di 13 kabupaten/kota, sedangkan di sisi lain ada 3 kabupaten/kota yang sudah melampaui target Indonesia Sehat tahun 2010 bahkan melampaui target MDGs. Penyebab kematian ibu dan bayi di beberapa kabupaten/kota masih seperti 1-2 dasawarsa yang lalu, seperti perdarahan, pre-eklampsia, dan partus lama sebagai penyebab kematian ibu terbanyak dan asfiksia sebagai penyebab kematian bayi terbanyak. Jaringan (networking) pelayanan KIA yang belum memadai di semua lini merupakan penyebab utama belum tercapainya target penurunan AKI dan AKB di Sumatera Barat sebagaimana yang telah ditetapkan dalam Indonesia Sehat 2010 maupun MDGs.

\section{Saran}

Penurunan AKI, AKB, dan AKABA Sumatera Barat memerlukan komitmen/kesepakatan yang kuat dan taat azaz, sejak dari pejabat pengambil keputusan (provinsi dan kabupaten/kota) sampai jajaran pelaksana pelayanan kesehatan. Penurunan AKI dan AKB tidak mustahil dapat dicapai dalam waktu yang lebih awal apabila jajaran kesehatan dan pemerintah daerah kabupaten/kota memi- 
liki komitmen yang kuat untuk mencapainya. Disamping itu, diperlukan adanya sumber daya manusia yang proaktif dan mampu dalam melaksanakan pemantauan wilayah setempat (PWS) KIA sehingga diperoleh data yang valid untuk mengukur AKI, AKB, dan AKABA. Tenaga penolong persalinan diharapkan juga dapat melaksanakan asuhan persalinan sesuai dengan standar praktek kebidanan sehingga dapat menurunkan AKI dan AKB. Untuk daerah kabupaten/kota yang AKI/AKB-nya sangat tinggi dianjurkan untuk dilakukan kajian lebih lanjut berupa studi yang intensif sehingga didapatkan data yang lebih valid.

\section{Daftar Pustaka}

1. Departemen Kesehatan Republik Indonesia. Profil kesehatan Indonesia 2004. Jakarta: Pusat Data dan Informasi Departemen Kesehatan Republik Indonesia; 2006.

2. Sudhabrata K. Bagian kebidanan dan kandungan. Kalimantan Timur: Rumah Sakit Umum Tarakan; 2004.

3. Departemen Kesehatan Republik Indonesia. Keputusan menteri kesehatan Republik Indonesia nomor: 1202/Menkes/VIII/2003 tentang indikator Indonesia sehat 2010 dan pedoman penerapan indikator provinsi sehat dan kabupaten/kota sehat. Jakarta: Departemen Kesehatan Republik Indonesia; 2003.

4. Vivi JS. Tingginya angka kematian ibu melahirkan. [diakses bulan Februari 2009]. Diunduh dari: http://www.sinarharapan.co.id.

5. Dinas Kesehatan Provinsi Sumatera Barat. Profil kesehatan. Sumatera
Barat: Dinas Kesehatan Provinsi Sumatera Barat; 2006.

6. Dinas Kesehatan Provinsi Sumatera Barat. Profil kesehatan. Sumatera Barat: Dinas Kesehatan Provinsi Sumatera Barat; 2008.

7. Dinas Kesehatan Provinsi Sumatera Barat. Profil kesehatan. Sumatera Barat: Dinas Kesehatan Provinsi Sumatera Barat; 2007.

8. Suriviana. Perdarahan pascapersalinan. [diakses bulan Februari 2009]. Diunduh dari: http://www.infoibu.com.

9. Anonim. Cegah perdarahan pascapersalinan untuk turunkan angka kematian ibu. Diunduh dari: http://www.kompas.co.id.

10. Oxorn H. Patologis dan fisiologis persalinan. Jakarta: Essentia Medica; 1990.

11. Wiknjosotro H. Ilmu kebidanan. Jakarta: Yayasan Bina Pustaka Sarwono Prawirohardjo; 2007.

12. Manuaba IBG. Ilmu kebidanan penyakit kandungan dan keluarga berencana untuk pendidikan bidan. Jakarta: ECG; 2002.

13. Bagian Ilmu Kesehatan Anak Fakultas Kedokteran Universitas Indonesia. Ilmu kesehatan anak. bagian 2. Jakarta: Infomedika; 2002.

14. Bagian Ilmu Kesehatan Anak Fakultas Kedokteran Universitas Indonesia. Ilmu kesehatan anak. bagian 3. Jakarta: Infomedika; 2002.

15. Anonym. Basics supported for institutionalizing child survival. Available from: http://www.basics.org.

16. Manuaba IBG. Penuntun diskusi obstetri dan ginekologi untuk mahasiswa kedokteran. Jakarta: EGC; 1995.

17. Kramer M. Maternal nutrition, pregnancy outcome, and health policy. CMAJ. 1998: 159-6.

18. WHO, UNICEF, UNFPA. Report. Women-friendly health services experiences in maternal care. Mexico City; 1999. 